Crisis? What Crisis? Economic recovery and support for independence in Catalonia

Running title: Economic recovery and support for independence

(Forthcoming in Regional Science Policy and Practice)

Germà Bel (Universitat de Barcelona, GiM-IREA \& OAP-UB)

Xavier Cuadras-Morató (Universitat Pompeu Fabra and BGSE)

Toni Rodon (London School of Economics and Political Science)

\begin{abstract}
Abstract: Many political commentators and politicians claim that the effects of the Great Recession account for the surge in support for independence in Catalonia. However, available evidence does not point to a significant role having been played by the economic crisis in this political process. To enhance our understanding of the potential effects of changing economic conditions, we extend our analysis to the subsequent period, when economic recovery had taken place in Catalonia. Even in this very different economic scenario, the same results are found: that is, no evidence of a systematic relationship between changes in economic variables and variations in support for independence
\end{abstract}

Contact author: Germà Bel. Department of Econometrics, Statistics and Applied Economics. John Keynes 1-11. 08034 Barcelona, Spain e-mail: gbel@ub.edu

Acknowledgements: This research has received financial support from the Spanish Ministry of Economy and Competitiveness (ECO2016-76866-R), SEV-2015-0563 and AEI/FEDER ECO2017-82596-P, and from the Government of Catalonia (2017 SGR644). No sponsor was involved in the design and implementation of the research. 


\section{Crisis? What Crisis? \\ Economic recovery and support for independence in Catalonia}

\section{Introduction}

The Catalan secession process has triggered an acrimonious political conflict in Catalonia and Spain. While views differ as to when support for independence began to strengthen (Bel, 2015), there is widespread consensus that summer 2010 marked a turning point insofar as this coincided with the ruling delivered by the Spanish Constitutional Court on the Catalan Statute of Autonomy. Thereafter, while independence was not a focus of the 2010 regional election, the question was a defining issue at the next regional elections. By October 2017, the conflict had developed into a major constitutional crisis and one that seems set to run and run.

Why support for independence should grow in Catalonia has been and remains a fiercely debated question. From within the pro-independence camp, such positive factors as self-government, institutional modernization, and economic betterment have been emphasized. In contrast, from within the anti-independence camp it is claimed that questions of identity, indoctrination by schools and the region's publicly owned media, and the effects of the economic crisis unleashed in 2009 are the main explanations for the rise in support for independence (Bel, 2015).

Systematic empirical evidence on the factors driving support for independence remains scarce. Serrano (2013) reports the somewhat limited influence of identity in explaining attitudes in favor of independence. Muñoz and Tormos (2015) analyze the influence of expectations regarding the economic consequences of independence on levels of support for the secessionist project. Other scholarly papers (i.e. Bosch and Espasa, 2014; Comerford, Myers and Rodríguez Mora, 2014; Cuadras-Morató and Raya, 2016) have discussed the potential economic effects of independence. 
Very little research has been conducted to date on the potential effects of the economic crisis. ${ }^{1}$ While several studies have hinted - without offering specific empirical evidence - that the economic conditions could have had an influence on the surge in support for independence (Rico and Liñeira, 2014 and Barrio et al., 2018), the evidence needed to shed light on this particular question has, to date, proved elusive. To the best of our knowledge, only two multivariate empirical studies have addressed the question for the Catalan case. ${ }^{2}$ First, Boylan (2015) uses survey data on the perception of the economic situation in Catalonia and other control variables to explain respondents' positions with respect to independence, and finds that - contrary to expectations - the perception of the economic situation is positively correlated with support for independence in a referendum: that is to say, survey respondents with a positive perception of the economic situation are more inclined to vote in favor of independence at a referendum. Second, Cuadras-Morató and Rodon (2019), drawing on both

\footnotetext{
${ }^{1}$ It should be borne in mind that the analysis of the effects of changing economic conditions (conjuncture) on support for independence is not the same as the analysis of the effect of the economic structure and capabilities (structure) on the support for independence. It is well established that the capacity and desire for economic self-management, and beliefs about the probability of economic improvement with independence, given the economic structure of Catalonia, are key factors in the structural support for independence (see, for instance, Bel 2015, p. 14, Table 1.4 ). What we are interested in here is not the effects of the economic structure, but rather the potential effects of changes in economic conditions (conjuncture), which have been hypothesized as explaining changes in support for independence, as stated above.

${ }^{2}$ Within the field of secessionist studies, and for the specific cases of Scotland and the Basque Country, Zirakzadeh (1989) observes that when unemployment is high, regional constituents turn to secessionist parties for economic solutions.
} 
disaggregated data at the municipal level and survey data, do not find any relationship between variations in employment and other economic variables due to the economic crisis and changes in political support for secession.

In this paper, we take this analysis a step further. If the impact of the economic crisis had a crucial impact on the increase in support for independence, then economic recovery should have had the opposite effect. Or, alternatively, and taking into account views on the asymmetry of the psychological and political effects of recessions and recoveries, economic recovery may have had political effects even if the recession did not. Thus, here, we analyze whether the economic recovery experienced in the last few years has had any significant impact on the recent evolution of support for independence. More specifically, we seek to determine whether there is any relationship between the differential intensity of the economic recovery and support for secessionist or unionist parties. In this way, we hope to enhance the limited nature of existing evidence on the relationship between the dynamics of the economy and support for independence.

\section{Political effects of economic crises and recoveries}

Analyses of the political effects of the 2008 financial crisis and the subsequent Great Recession have generated a huge amount of literature among social scientists (for a general overview see, for example, Algan et al., 2017 and Dustmann et al., 2017 and references therein). One of the main ideas to emerge from this line of research is that the negative economic consequences of the crisis (including, unemployment and lower personal income levels) might, at least in part, be behind the significant phenomena that have had such a marked impact on the political scenario in various countries. Some of these changes have taken the form of major constitutional shifts (e.g. Brexit in the United 
Kingdom), the emergence of new political actors (extreme left and right parties, for instance) and a general shift in both the political attitudes and voting behavior of citizens.

Although a number of recent studies emphasize the asymmetry of the psychological and political effects of recessions and recoveries (De Neve et al., 2018 and Matakos and Xefteris, 2017), many observers have taken this general argument to the next level and argue that "an improving economy could be enough to restore support for the status quo ante" (Dustmann et al., 2017, p.1). Despite such suggestions, empirical studies have yet to validate this claim. The current paper explores this line of reasoning, focusing on the relationship between variation in economic variables and electoral support for pro-independence parties during the period of the economic recovery which in Catalonia started at the end of 2013, after a very deep and socially disruptive economic recession. Our results - namely, the absence of a relationship between changing economic and political variables - are in line with those reported by Cuadras-Morató and Rodon (2019).

During the period 2008-2013, Catalonia was hit by a very deep recession, with a negative average economic growth rate equal to -1.5 and an unemployment rate that peaked at $23.1 \%$ in 2013 . Parallel with this, since 2010 there has been a marked upsurge in support for pro-independence positions among the Catalan population, both in opinion surveys and electoral contests (for more details on this see Bel, 2015 and Cuadras-Morató, 2016). This, together with the analysis of the disaggregated data in Cuadras-Morató and Rodon (2019), suggests that either economic motives were relatively unimportant in accounting for this greater support for independence or, alternatively, that citizens took the deteriorating economic situation of the country (sociotropic evaluation) into greater consideration than they did their personal circumstances. 
Subsequent to these events, Catalonia experienced a period of consolidated recovery (2014-2017) with an average annual economic growth equal to 3.1 and an unemployment rate that rapidly fell to $13.4 \%$ in 2017. Despite this marked improvement in the general economic scenario, the degree of support for independence did not fall significantly, undermining to some degree the argument of a connection between the economic situation and politics based on sociotropic considerations. Moreover, our empirical results are consistent with the absence of a significant relationship between the economic recovery and changes in electoral support for pro-independence parties at the level of municipalities during that recovery. Our main hypothesis, therefore, is that factors unrelated to the changing economic conditions are likely to constitute the most salient reasons for the political changes that have occurred in Catalonia since 2010.

Our view regarding these results is that the shock affecting Catalan politics extends well beyond the mere consideration of the state of the economy (although this is not to deny that the Great Recession may indeed have had a role to play). The economic crisis coincided in time with other intrinsic political problems that led to a dramatic drop in trust in Spanish political institutions (Tormos, 2019), produced considerable dissatisfaction with the overall political system and triggered a radical shift in political preferences and electoral choices, with pro-independence positions being favored in the institutional setup. This line of reasoning is similar to Vidal's (2018), who shows that voting for new parties in Spain after the shock of the Great Recession was mainly due to dissatisfaction with the overall political system and went far beyond considerations related to the state of the economy (see also Hernández and Kriesi, 2016).

\section{Factors driving support for independence in Catalonia. Related literature}

The empirical analysis of the micro-level factors explaining the increase in support for independence has been additionally conducted in several studies that have used the 
barometers reported by the Centre d'Estudis d'Opinió (or the CEO, the Catalan Government's Opinion Studies Center) as their raw material, most notably those by Prat i Guilanyà (2012), Serrano (2013), Muñoz and Tormos (2015) and Boylan (2015). ${ }^{3}$

Prat i Guilanyà (2012) analyzes the factors that account for the support for independence in 2012 and compares them with the factors that explained this support in 2005. To do so, he specifies a multinomial model in which the dependent variable is preference for an independent Catalonia as obtained from surveys conducted by the CEO. Prat i Guilanyà's empirical results indicate that between 2005 and 2012, Catalan national identity played a prominent role in accounting for the increase in support for independence. The youngest age group (18-34 year olds) reveals a somewhat higher level of support than the older age groups (though this does not always reach statistical significance). Interestingly, the difference between the youngest and oldest (over 64 years old) groups is not so great in terms of their support for independence.

Serrano (2013) explores the social and political factors influencing support for independence using a logistic regression model in which the dependent variable is support for independence. Among the different variables he considers, national identity has a relevant impact, but other, more pragmatic, factors are also important. Among these, the desire for fiscal autonomy - collection and management of taxes at the regional level -

\footnotetext{
${ }^{3}$ Rico and Liñeira (2014) conducted an empirical analysis of the factors explaining the fall in electoral support for Convergència i Unió in the regional election held in 2012 (at that time, the leading sovereigntist party). This study cannot, however, be compared with those reviewed in this section. Having said that, it is worth recalling that in addition to reporting their empirical results, the authors discuss the hypothesis that the rise of Catalan secessionism was an effect of the dissatisfaction provoked by the economic crisis, noting that if this was truly a crucial factor, then "the proindependence tide will therefore probably recede as the economy recovers." (p. 273).
} 
appears to be highly relevant in accounting for support for independence, implying that that prospects of improved welfare contribute to explaining the respondents' proindependence positions. However, no other economic variables are considered, so the effect of the economic crisis is not explored as a potential driver of support for independence.

Muñoz and Tormos (2015) study the factors that might account for the support for independence in Catalonia by drawing on the database of the CEO barometer for June 2012. The authors use multivariate regression techniques that take into account several explanatory variables, including, most notably, those related to national identity, those of an 'instrumental' type (e.g., economic motives) and objective characteristics of the individual, such as age. Age has no influence on support for independence, either in terms of its dimension, or its statistical significance. In contrast, the study's results indicate a positive and significant influence of Catalan national identity, and also of economic motives among dual identity individuals, approached as the expectation of improvement of economic welfare after independence.

Also drawing on data obtained from CEO surveys, Boylan (2015) employs binary logistic regression estimations to study the factors that explain support for independence as a constitutional status, and also the willingness to vote in favor of independence in a referendum. As in Muñoz and Tormos (2015), he uses variables reflecting concerns about fiscal powers, identity-related factors, and personal conditions. Furthermore, he includes perception of the economic situation in an attempt at capturing the impact of the economic crisis, as the data used are drawn from surveys conducted in 2013 and earlier. In common with the other studies, Boylan finds that the desire for increased fiscal power and selfreported identity are both positively related to support for independence as a constitutional status and to a yes-vote in a referendum. As for the assessment undertaken 
of the economic situation in Catalonia, this does not present any significant association with the support for independence as constitutional status. However, perception of the economic situation is positively related to the willingness to vote yes in an independence referendum. As the author notes, "these results bring into question popular claims that Catalans agitate for independence based on the region's economic problems" (Boylan. 2015: 776).

Cuadras-Morató and Rodon (2019) use data from the CEO surveys and the regional elections held in 2006 and 2015 to estimate the actual increase in support for independence among Catalan voters at the level of the municipalities. Their empirical models use this change in political preference as the dependent variable, while the explanatory variables are changes in economic variables, including the number of employed and unemployed workers, the number of firms and income per capita. The main objective of their study is to determine whether the negative economic effects of the Great Recession impacted growth in support for independence in the political preferences of Catalan citizens. They find that "Higher levels of destruction of jobs, disappearance of firms, or income loss in different municipalities do not appear to lead to higher increases in secessionist support" (Cuadras-Morató and Rodon, 2019: 2). Similarly, using individual data from all the CEO surveys conducted between 2006 and 2015, they find that employment status, income, class and the assessment of one's personal economic situation are not determinant factors of support for independence.

The main contribution of our study is to extend the foregoing analyses into a period characterized by economic expansion, given that since 2014 the Catalan economy has recovered from the very deep recession that affected the region between 2008 and 2013. Even in such a different economic scenario - that of economic recovery - no 
relationship between changes in economic variables and increase/decrease in support for independence is found.

\section{Data and Methods}

In order to shed light on the relationship between the recovery of the Catalan economy and electoral support for pro-independence parties, our empirical analysis follows Cuadras-Morató and Rodon (2019) and exploits the heterogeneous impact of economic growth on secessionist support. In other words, our analysis compares secessionist support in those municipalities experiencing a stronger economic recovery with the support in municipalities where the economy recovered at a slower pace — or did not recover at all. The economic recovery followed a spatially divergent pattern across municipalities, a variation that we exploit in an attempt at relating it to secessionist support. If there is any link between economic growth and secessionist support, we should observe a statistically significant relationship between the two variables, even when adjusting for other potential confounders.

Our outcome is the growth ratio of secessionist support for the period 2015 to 2017. ${ }^{4}$ This has been calculated in two steps: We first summed the share of votes obtained by secessionist parties in 2015 ( $J x S$ and CUP) and in 2017 (JxCat, ERC, and CUP). We then took the growth ratio between the two indicators. ${ }^{5}$

\footnotetext{
${ }^{4}$ In both elections a percentage of the adult population did not vote. Thus, what we measure is the change in support for independence as expressed in regional elections. Note that turnout was higher in $2017(79.1 \%)$ than in 2015 (74.9\%) [https://www.idescat.cat/pub/?id=elepc\&n=389], but on both occasions it reached historical levels. If we run robustness checks controlling for changes in turnout, our results do not change.

${ }^{5}$ If, instead of the share of the votes received by secessionist parties, we use the absolute number of votes, we obtain the same results.
} 
Figure 1 shows the distribution of the growth rate of support for independence between 2015 and 2017. As can be seen, the distribution is normal, with a mean of 0.7 , a standard deviation of 4.0, a minimum of -21.0 and a maximum of 25.6. Thus, the increase in support for pro-independence parties was heterogeneous, although most municipalities experienced a somewhat modest change. As documented in Cuadras-Morató and Rodon (2019), the increase in secessionist support mainly occurred between 2006 and 2015 .

\section{(insert Figure 1 around here)}

Figure 1: Distribution of the growth rate of support for independence between 2015 and 2017

Several economic variables potentially measure the positive impact of the economic recovery in Catalonia after the Great Recession and are available on at least a yearly basis at the level of municipality: namely unemployment, employment, and the number of firms. They are available for all municipalities (946 observations). We are aware that data at the municipal level may not provide us with the precise figures for the variables in which we are interested, but note as well that the data we use in our analysis are the best available. Yet, in line with recent research reports (Larsen et al., 2019; Ansell, 2019), the local economy is important in shaping people's political behavior.

\section{Unemployment}

The unemployment data available at the municipality level are the "registered unemployed", that is, the number of workers residing in the municipality registered as unemployed in the public job service offices of the regional government. The total number of registered unemployed workers in Catalonia fell by 19 per cent between 2015 and 2017. 


\section{Employment}

The number of affiliated workers to the Social Security system residing in the municipality is taken as the measure to approximate employment. Total employment increased in Catalonia by 7 per cent during the period 2015-2017.

\section{Number of firms}

The number of firms in each municipality is approximated by the number of contribution accounts to the Social Security system. Firms may use a single contribution account for all their workers in a province or have a different contribution account for each establishment they operate in the province. This means that the figure is only an approximation of the number of firms in each municipality since some firms might have an establishment in one location and no contribution account there if its workers are associated to a contribution account of the same firm in a different location. Despite this drawback, the information on contribution accounts is the best available data to approximate the number of firms located in a given municipality. The total number of firms in Catalonia increased by 3 per cent during the period 2015-2017.

The data on employed and unemployed workers and quotation centers are available quarterly. In order to compute the difference between 2015 and 2017, we choose the value corresponding to the fourth quarter (December) because the 2017 regional elections took place in this month. Also, in this way, we avoid seasonality problems.

Figure 2 shows the distribution of the growth rate of the three explanatory variables of interest. In all cases, the distribution of the growth rate covers both positive and negative values, thus indicating that some Catalan municipalities recovered from the 
effects of the economic crisis at a faster pace than others. ${ }^{6}$ In our empirical models, we specifically use this uneven intensity in the economic recovery to examine its relationship with secessionist support.

\section{(insert Figure 2 around here)}

Figure 2: Distribution of the growth rate of unemployed, affiliates to the Social Security system and Quotation Centers (2017-2015)

The empirical analysis also adjusts for several potential confounders that may affect the relationship between the economic recovery and the vote for secessionist parties. The first, and probably most important, control is the percentage of support for secessionist parties in 2015. Since the variation in support could depend strongly on the baseline level (for instance, in some municipalities there might be a ceiling effect), it is essential to analyze the effect of the economic recovery on the growth ratio of secessionist support net of the starting point observed for each municipality. ${ }^{7}$

Second, as secessionist support negatively correlates with the percentage of people born in other Spanish regions, all models include it as a control. Third, models also include the percentage of the population who are 65 years and older-secessionist support is lower among the older population. Fourth, pro-independence support is generally higher in less populated areas, hence population density is an additional and

\footnotetext{
${ }^{6}$ The distribution of the growth rate of unemployed shows a few outliers. All these values correspond to small municipalities. We have carried out sensitivity checks to analyse the stability of the findings once these values are removed. As it stands, these results remained unaffected.

${ }^{7}$ It might be argued that adjusting for the baseline is not necessary as a period of two years (20152017) is not overly long and, therefore, the empirical models are already controlling for the baseline effect. If we exclude this control from the models, our results are essentially the same.
} 
relevant control. Fifth, as a proxy for secessionist mobilization, we include the percentage of people who speak Catalan and a categorical indicator distinguishing whether the mayor in the municipality belongs to a pro-independence party or not. In sum, we include relevant controls that, as stated in previous studies, might affect the relationship between economic recovery and secessionist support (Serrano 2013, Muñoz and Tormos 2015, Rodon 2015, and Cuadras-Morató and Rodon, 2019).

Our strategy relies on conventional OLS regressions. Errors are clustered at the province level. In addition, since we want to remove unobserved heterogeneity as much as possible, we include region fixed effects, which allows us to compare the effect of the economic recovery on secessionist support within a given region. ${ }^{8}$

\section{Results}

Table 1 reports the OLS estimates of the effect of the various economic indicators on the growth rate of electoral support for pro-secessionist parties. M1 examines the effect of the growth rate of unemployment, M2 the effect of the growth rate of employment, and M3 the effect of the growth rate in the number of firms. M4 includes all three variables in one single model. Even though the correlation between the three economic variables is not strong, the models are shown separately in order to visualize the stability of the coefficients.

\footnotetext{
8 There are seven regions in Catalonia, which correspond to vegueries. Vegueries are administrative territorial jurisdictions that represent symbolic areas of reference. Although the number of municipalities varies, a vegueria generally has more than 110 municipalities. In addition, it is important to note that in some of the municipalities there are missing values for some of the economic indicators, which means the number of cases differs across models.
} 


\section{(insert Table 1 around here)}

Table 1: Effect of the economic recovery on the growth rate of electoral support for pro-secessionist parties

As Table 1 shows, the indicators of the intensity of the economic recovery are not statistically significant. Results essentially show that the economic recovery between 2015 and 2017 was not associated with an increase or a decrease in the share of the votes obtained by pro-secessionist parties. In other words, we observe that municipalities that experienced a decrease in the number of unemployed, an increase in the number of those registered to the social security system, or an increase in the number of quotation centers were not more likely to see an increase or decrease in the vote for pro-secessionist parties. This null finding is shown in models M1-M3, in which each of the variables is included separately, and in M4, when all three indicators are collapsed into a single model.

The control variables behave as expected. We observe that the growth in prosecessionist support is correlated with the percentage of people that usually speak Catalan, albeit at the $90 \%$ level. On the other hand, it is negatively correlated with the vote share obtained by pro-sovereign parties in 2015. This essentially indicates that support for secession grew less in places where its support was already high. This indicates the existence of a ceiling effect, probably explained by the high level of mobilization among secession supporters in the 2015 election. This same rationale may underpin the negative effect of the pro-sovereignty mayor dummy.

In further analyses, we also unpack the outcome and, instead of grouping all the secessionist parties together, we created different indicators, one for each of the parties. Since secessionist parties have different ideological profiles (ranging from the extremeleft to the center right), the economic recovery might have had a positive effect for some and a negative effect for others. Aggregating outcomes might cancel out the effect of changing economic conditions on secessionist support. However, we do not find any 
evidence of this. Once again, we find a non-statistically significant effect between the economic recovery and changes in the share of the votes obtained by the different prosecessionist parties. We do not report these results here to avoid redundancy (available upon request).

Next, we replicate the exercise by focusing on the electoral support received by pro-unionist parties. It might be argued that the effect of the economic recovery is not homogeneous, and that it might affect the two political sides differently. In other words, the economic recovery might not affect secessionists, but it might drive pro-unionist support up or down. Hence, we check this potential pattern by using the share of the votes obtained by unionist parties as an outcome — share of the votes received by $C$ 's, $P S C$, and $P P$ - and replicating the models shown above.

Table 2 reports the results. As can be seen, in general, we once again observe a non-statistically significant relationship between the economic indicators and the variation in the share of the votes obtained by unionist parties.

\section{(insert Table 2 around here)}

Table 2: Effect of economic recovery on the growth of electoral support for unionist parties

Again, our control variables behave as expected. The percentage of people usually speaking Catalan is negatively related to the growth in unionist support. In addition, our results report that support for secession grew less in places where its support was already high, whereby indicating the existence of a ceiling effect. Finally, population density is negatively related to the growth of electoral support for unionist parties, perhaps reflecting the fact that their voters were mobilized earlier in urban centers than in rural and less densely populated areas.

Lastly, we undertook several robustness checks. As explained before, we used data from 2015 and 2017 to construct our indicators of economic recovery. It might be 
argued that this decision is arbitrary, which in turn increases the likelihood of selecting on the dependent variable. If the latter is the case, our results will be biased. Accordingly, we re-constructed our economic indicators using new temporal reference points. The first set of indicators takes into account the growth rate in all three measures between 2013 and 2017. The other set of indicators uses 2014 and 2017. We have also re-run all the models using these new set of indicators. The estimations can be seen in Tables A and B in the appendix. Results do not change. In other words, all the empirical analyses fail to prove a statistically significant association between the spatial distribution of the economic recovery and changes in support for pro-secessionist parties. Additionally, we have re-run the models with alternative specifications, the most important being weighted least squares models (WLS), which take into account the size of the different units. We have also discarded misspecification problems by conducting a Ramsey test. Finally, we conducted an individual-level analysis using surveys to analyze the relationship between an individual's employment status and support for independence. The results are once again consistent with our story.

\section{Conclusion}

Following the Great Recession, much research has been devoted to analyzing the potential impact of the economic crisis on shifts in the political scenario of several countries. Following this line of reasoning, many political analysts and politicians in Spain seemed willing to blame the economic crisis for the increase in support for Catalan independence. However, the empirical evidence available to date fails to identify a significant role for the economic crisis in the surge in support for secession. In this paper we have gone one step further and examined whether the subsequent economic recovery in Catalonia has had any significant impact on the Catalan political process. 
To investigate any potential relationship between the recovery of the Catalan economy and electoral support for independence, our empirical analysis seeks to explain the drivers of change in electoral support for the pro-independence parties following economic recovery. Because the economic recovery was heterogeneous, we have compared support for independence in municipalities that experienced a faster economic recovery with that in municipalities where the economic recovery followed a slower pace — or did not recover at all. To do so, based on data from the most recent regional elections in Catalonia, economic variables capturing the economic recovery, and controlling for several socio-political factors, we have estimated a model to explain the change in electoral support for both pro-independence and unionist parties. Although the data we use in the paper are subject to certain limitations, they allow us to contribute to the recent literature analyzing the relationship between political attitudes and economic variables using territorial data (Dippel et al., 2015).

Our estimations show that the change in support for independence was positively associated with the share of Catalan-speaking population in each municipality, which is consistent with previous findings. We find a negative relationship between the change in support for independence and the previous electoral performance of pro-independence parties, which suggests the likely existence of a ceiling effect attributable to the share obtained by pro-sovereign parties in 2015 following an intense process of mobilization. However, we do not find any significant relationship between the economic recovery and the change in support for independence. Likewise, we do not find any such relationship when we examine the change in support for anti-independence parties.

All in all, our results do not point to any significant effect of the changing economic situation on support for independence. While previous evidence does not support claims that the political process unleashed in Catalonia was driven by the effects 
of the economic crisis, the main results of our research indicate that the economic recovery has likewise failed to restore the status quo. We leave for further research an analysis of how individuals integrated into their decision-making process the changing economic conditions and how this might be related to a different type of crisis, the institutional crisis that affected Spain during these years and which might have been a more influential factor in the surge of support for independence.

\section{References}

Algan Y, Guriev S, Papaioannou E, Passari E (2017) The European Trust Crisis and the Rise of Populism. Brookings Papers on Economic Activity Fall: 309-382

Ansell, B (2019) The Politics of Housing, Annual Review of Political Science, 22(1): 165185.

Barrio A, Barberà O, Rodríguez-Teruel J (2018). “Spain steals from us!” The "populist drift" of Catalan regionalism. Comparative European Politics 16: 993-1011

Bel G (2015) Disdain, Distrust and Dissolution. The Surge of Support for Independence in Catalonia. Sussex Academic Press, Eastbourne

Bosch N, Espasa M (2014) La viabilidad económica de una Cataluña independiente. Revista de Economía Aplicada XXII (64): 135-162

Boylan B M (2015) In pursuit of independence: the political economy of Catalonia's secessionist movement. Nations and Nationalism 21: 761-785

Comerford D, Myers N, Rodríguez Mora J V (2014) Aspectos comerciales y fiscales relevantes para evaluar las consecuencias económicas de una hipotética independencia de Cataluña. Revista de Economía Aplicada XXII (64): 85-130

Cuadras-Morató X (ed.) (2016) Catalonia: A New Independent State in Europe (A debate on secession within the European Union), Routledge, Abingdon 
Cuadras-Morató X, Raya J M (2016) Boycott or Buycott? Internal Politics and Consumer Choices. The BE Journal of Economic Analysis and Policy 16: 185-218

Cuadras-Morató X, Rodon T (2019) The dog that didn't bark: on the effect of the Great Recession on the surge of secessionism. Ethnic and Racial Studies forthcoming

De Neve J-E, Ward G, De Keulenaer F, Van Landeghem B, Kavetsos, G, Norton M I (2018) The Asymmetric Experience of Positive and Negative Economic Growth: Global Evidence Using Subjective Well-being Data. Review of Economics and Statistics 100: 362-375

Dippel, C, Gold, R. Heblich, S. (2015) Globalization and Its (Dis-)Content: Trade Shocks and Voting Behavior, NBER Working Paper Series, 21812 (http://www.nber.org/papers/w21812)

Dustmann C, Eichengree B, Otten S, Sapir A, Tabellini G, Zoega G (2017) Europe's Trust Deficit (Causes and Remedies) CEPR Press, London

Hernández E, Kriesi H (2016) The electoral consequences of the financial and economic crisis in Europe. European Journal of Political Research 55: 203-224

Larsen M, Hjorth F, Dinesen P, Sonderskov K (2019) When Do Citizens Respond Politically to the Local Economy? Evidence from Registry Data on Local Housing Markets, American Political Science Review 113(2): 499-516.

Matakos K, Xefteris D (2017) Economic Insecurity and Political Stability: A Case for Growth-Targeting Systemic Vote. SSRN: https://ssrn.com/abstract=2567834

Muñoz J, Tormos R (2015) Economic expectations and support for secession in Catalonia: Between causality and rationalization. European Political Science Review 7: 315-341.

Prat i Guilanyà S (2012) El suport a la independència de Catalunya. Anàlisi de canvis $i$ tendències en el període 2005-2012. Papers de Treball del CEO, Barcelona. 
Rico G, Liñeira R (2014) Bringing Secessionism into the Mainstream: The 2012 Regional Election in Catalonia. South European Society and Politics 19: 257-280

Rodon T (2015) Una visió geogràfica de la independència de Catalunya. Barcelona: Institut d'Estudis de l'Autogovern.

Serrano I (2013) Just a Matter of Identity? Support for Independence in Catalonia. Regional \& Federal Studies 23: 523-545

Tormos R (2019) Measuring Personal Economic Hardship and Its Impact on Political Trust During the Great Recession. Social Indicators Research forthcoming

Vidal G (2018) Challenging business as usual? The rise of new parties in Spain in times of crisis. West European Politics 41: 261-286

Zirakzadeh C E (1989) Economic changes and surges in micro-nationalist voting in Scotland and the Basque region of Spain. Comparative Studies in History and Society 31: 318-339.

\section{Appendix}

(Insert Figure A around here)

(Insert Figure B around here)

(Insert Figure C around here)

(Insert Table A around here)

(Insert Table B around here) 
Table $\mathrm{C}$ and Table $\mathrm{D}$ replicate the main models in the manuscript but employing different reference points to capture the economic recovery. ${ }^{9}$ While Table $\mathrm{C}$ measures the economic recovery comparing 2013 and 2017, Table D focuses on 2014 to 2017. As it can be seen, in both cases results are substantially the same.

Table E reports Weighted Least Squares (WLS) estimations and Table F replicates the analysis to municipalities smaller than 500 inhabitants.

(Insert Table $\mathrm{C}$ around here)

(Insert Table D around here)

(Insert Table E around here)

(Insert Table $\mathrm{F}$ around here)

\footnotetext{
${ }^{9}$ Including the vote share obtained by secessionist parties in 2015 means that we are including a variable that realizes itself after the temporal point used to measure the economic recovery (2013 or 2014). This might imply a post-treatment bias. Yet, even if we exclude it, results are substantially the same. Therefore, we decided to keep it in order to make the models comparable to those reported in the manuscript.
} 